\title{
AGRICULTURAL DEVELOPMENT PROGRAMME'S (ADP'S) EFFECTIVENESS IN THE USE OF MASS MEDIA FOR AGRICULTURAL INFORMATION DISSEMINATION TO FARMERS IN IMO STATE, NIGERIA
}

\author{
*Akwiwu, Uzoamaka N. and Patrick, Ruby E. \\ Department of Agricultural Economics/Extension and Rural Development, Imo State University, \\ Owerri. Nigeria \\ E-mail: uzoakwiwu@yahoo.co.uk, 08037783241
}

\begin{abstract}
This study sought to assess ADP's effective use of mass media in agricultural information dissemination to farmers in Imo state, Nigeria. A total of 120 farmers were selected through multi-stage sampling technique. Interview schedule was used to elicit information on farmers' accessibility of agricultural information through mass media, perceived level of use of mass media in receiving agricultural information among farmers and to determine the perceived effectiveness of ADP's use of mass media in agricultural information dissemination. Data collected were analyzed using frequency distribution, percentages, mean, and PPMC to test the hypothesis at 0.05 level of significance. The result shows that the majority (88.3\%) of the respondents accessed agricultural information through radio. Perceived level of use of mass media in receiving agricultural information (58.3\%) was low. Use of mass media in agricultural information dissemination by ADP (59.2\%) was ineffective. There was significant relationship between the perceived level of use of mass media in receiving agricultural information $(r=0.64)$ and the perceived effectiveness of ADP's use of mass media in agricultural information dissemination. The use of mass media in agricultural information dissemination in Imo State by $A D P$ was ineffective. This work recommends that ADP in Imo State establish their own indigenous mass media tools to ensure its effective use by extension agents and control of content for agricultural information dissemination.
\end{abstract}

Keywords: ADP, Agricultural information dissemination, Mass media

https://dx.doi.org/10.4314/jafs.v17i2.4

\section{INTRODUCTION}

Information is knowledge obtained from investigation, study, or instruction (Merriam Webster dictionary, 2017). Information can also be seen as a package or collection of relevant issues concerning a particular sector, discipline or entity. Therefore, agricultural information can be regarded as a package or collection of relevant issues on agriculture. For agricultural development which is the ultimate aim for the establishment of agricultural extension agencies to be achieved, agricultural information has to be disseminated. Cambridge University Press (2009) Journal of the Faculty of Agriculture and Veterinary Medicine, Imo State University Owerri website: www ajol.info 
defines dissemination as "to spread or give out something, especially news, information, ideas etc., to a large number of people". In line with this, it is worthy of note that communication is a vital tool in the dissemination of agricultural innovation and technology which is information.

For farmers to benefit from agricultural technologies, they must first have access to information and learn how to effectively utilize them in their farming system and practices. This is the foundation of agricultural extension agencies all over the world. These extension agencies make use of different approaches, means and media in transferring improved agricultural technologies to the end users who are predominantly farmers.

Adikari (2014) stated that agricultural extension is a service which helps or assists people, particularly farm families through educational procedures in promoting their farming practices and techniques, increasing their production efficiency and income, buffering their standard of living and lifting their social, economic and educational standard of rural life. Agricultural extension or advisory services comprises the entire set of organizations that support people engaging in agricultural production and facilitate their efforts to solve problems; create link to markets and other players in the agricultural value chain; and obtain information, skills, and technologies to improve their livelihoods (Memon et al, 2014).

The establishment of Agricultural Development Programmes (ADPs) in all States of the federation in Nigeria reformed extension service. According to Omonijo et al (2014), ADP aims at increasing food production for rural dwellers and raising the income level of small scale farmers by making provision for improved seeds, fertilizer, pesticides, credit facilities and infrastructural facilities. So the goal of the government in establishing the ADPs is to achieve self-sufficiency in food and fibre production for both human and industrial consumption. The success of agricultural extension services in developing countries largely depends on the nature and extent of use of mass media in mobilization of people for development. Sharma (2012) refers to mass media as the system that provides information to many people. Mass media methods in agricultural information dissemination generally, are useful in reaching a wide audience at a fast rate, they are useful as sources of agricultural information to farmers and as well constitute methods of notifying farmers of new development and innovations. They could equally be important in stimulating farmers' interest in new ideas and practices (Ani, Undiandeye and Anogie, 1997). Once stimulated or made aware through mass media, farmers may seek additional information from neighbours, friends, extension agents or progressive farmers in the area.

Effectiveness of mass media facilitates the adoption of innovation especially when actively put in use and by that encourages agricultural development. Khan, Rahman and Uddin (2017) defines effectiveness as the influence or capacity or validity of something to produce the expected results. Effectiveness in mass media can therefore be referred to as the capacity of mass media to produce expected result. Some of the major mass media tools for agricultural 
information dissemination in Nigeria are radio, television, print, and most recently, telephones and internet.

There is a need for a maximal use of mass media for information dissemination at this time as ADP is yet to fulfill her mandate. Bello and Obinne (2012) believes that the major setback in agricultural production in Nigeria is not lack of recommended practices needed for economic growth and rural transformation but that of disseminating the recommended practices to end users. Mohammed and Olabode (2007) stated that in Nigeria, the ratio of agricultural extension agents to farmers (1:4000), makes it impossible to reach all farmers by inter personal means. This is sequel to the findings of Njoku (2016) that the ratio of extension agents to farmers in Nigeria especially in Imo State is grossly inadequate making extension workers to reach insignificant number of the farmers; hence a wide gap exists between available knowledge of improved technology and actual practice. This has had negative effect on attempts to increase food production.

Exhaustive use of mass media can address these issues and deliver agricultural information to a large number of farmers quickly. However, in spite of the fact that mass media method of agricultural technology dissemination has been in use yet the mass effectiveness of agricultural technology adopted through it has not been felt (Nwankwo and Orji, 2013). The minimal contribution of mass media in agricultural development necessitates a review on the effectiveness of ADP's use of mass media for agricultural information dissemination so as to proffer solution if need be.

\section{OBJECTIVES OF THE STUDY}

The objectives were to:

i. ascertain farmers' accessibility to agricultural information through various mass media;

ii. ascertain the perceived level of use of various mass media in receiving agricultural information among farmers; and

iii. determine the perceived effectiveness of ADP's use of mass media in agricultural information dissemination

\section{Hypothesis}

$\mathrm{Ho}_{1}$ There is no significant relationship between perceived level of use of mass media in receiving agricultural information and perceived effectiveness of ADP's use of mass media in agricultural information dissemination.

\section{METHODOLOGY}

The study was carried out in Imo State, Nigeria. Imo State is in the South East zone of Nigeria. The state is made up of twenty-seven (27) Local Government Areas. Extension service in Imo State is mostly carried out by Imo State Agricultural Development Programme (ADP). Imo ADP is divided into three (3) agricultural Zones, namely: Owerri, Okigwe and Orlu Zone. Owerri Journal of the Faculty of Agriculture and Veterinary Medicine, Imo State University Owerri website: www ajol.info 
agricultural zone is made up of eleven Local Government Areas. Okigwe agricultural zone is made up of six Local Government Areas and Orlu agricultural zone consist of ten Local Government Areas.

Multi stage sampling method was adopted in the selection of farmers. The first stage was purposive selection of seven (7) Local Governments (Ohaji Egbema, Owerri West, Ngor Okpala, Ihitte Uboma, Onuimo, Orsu, and Oru East) from the three agricultural zones in Imo State. This selection was based on high level agricultural involvement of the LGAs in the agricultural zones. The second stage was the random selection of twelve (12) communities from the seven Local Government Areas selected. The third stage was the random selection of ten (10) farmers from each of the communities making a total of one hundred and twenty (120) farmers.

Interview schedule was used to collect quantitative data from the selected farmers, while indepth interview (IDI) was used in collecting qualitative data from key informants in ADP. Data collected were analyzed using descriptive statistics such as frequencies, percentages and mean, and hypothesis tested using PPMC at 0.05 level of significance

To ascertain the accessibility of agricultural information through mass media, the respondents were presented with a list of twelve possible mass media tools from which they can access agricultural information. Respondents were to choose from response options of Yes and No to indicate access and non-access to agricultural information from each medium listed.

The level of perceived use of mass media in receiving agricultural information was measured using 25 statements that can help determine the level of use of mass media. Some of the statements were negatively worded while some were positively worded. Respondents were asked to express their disposition on a five point Likert type scale of Strongly Disagreed (SD), Disagreed (D), Undecided (U), Agreed (A) and Strongly Agreed (SA). Strong agreement to a positively worded statement was assigned five points and strong disagreement, one. Likewise, a strong disagreement to a negatively worded statement was assigned five points while a strong agreement was assigned one. The highest possible score was one hundred and twenty-five (125) while the lowest possible score was twenty-five (25).

Individuals' scores and mean were computed. On the basis of the mean score of 46.53, respondents were categorised into two. Respondents with scores equal to, or above the percentage mean score were categorized as having high level of use of mass media while the respondents with scores below the percentage mean score were categorized as having low level of use of mass media in receiving agricultural information.

The perceived effectiveness of ADP's use of mass media in agricultural information dissemination was measured using 30 statements that can help determine the effectiveness of mass media use. Some of the statements were negatively worded while some were positively worded. Respondents were asked to express their disposition on a five point Likert type scale of Strongly Disagreed (SD), Disagreed (D), Undecided (U), Agreed (A) and Strongly Agreed (SA). Strong agreement to a positively worded statement was assigned five points and strong Journal of the Faculty of Agriculture and Veterinary Medicine, Imo State University Owerri website: www ajol.info 
disagreement, one. Likewise, a strong disagreement to a negatively worded statement was assigned five points while a strong agreement was assigned one. The highest possible score was one 150 while the lowest possible score was 30 .

Respondents' scores were calculated and the mean derived. Based on the mean score of 53.9, respondents were categorized into two. Respondents with scores equal to, or above the percentage mean score were categorized as effective while those below the percentage mean score were categorized as ineffective.

\section{RESULTS AND DISCUSSION}

\section{Farmer's accessibility to agricultural information through mass media tool}

Table 1 shows that respondents had access to radio (88.3\%), television (44.2\%), telephone $(2.5 \%)$ and internet $(12.5 \%)$. None of the farmers reported access to the print media tools. This implies that farmers accessed information mostly through radio. This is in support of the findings of Ani and Baba (2009), that the majority of farmers sourced their agricultural information from radio.

Television was not in use as compared to radio in receiving agricultural information from the Table. This corroborates with the statement of a staff at Imo ADP during the in-depth interview. He stated that:

\section{Television is not frequently used as radio because of high cost of disseminating agricultural information through television stations.}

From the result also, the internet was used minimally. This finding is supported by the statement of a staff of Imo ADP during the in-depth interview that:

Internet is not in use as a means of agricultural information dissemination because of lack of internet services and the poor electricity supply in rural areas

It could therefore mean that those who used internet at all sought information independently. The result supports the statement of Umerah (2012) that the use of modern advanced technologies such as internet and other computerized system technologies still face a lot of challenges in developing countries. The print media were not in use for agricultural information dissemination in the study area. This is in contradiction to the statement of a subject matter specialist in Imo ADP that:

'Bulletins and handbooks were in use in reaching farmers with agricultural information. Bill boards and posters were in use before but not anymore'.

Therefore, whereas newspaper as one of the print media was available, it was not still in use in receiving agricultural information among farmers in Imo State. 


\section{Perceived Level of Use of Mass Media in Receiving Agricultural Information}

Table 2 shows level of use of mass media in receiving agricultural information. The result indicates that the perceived level of use of mass media in receiving agricultural information was low $(58.3 \%)$. This implies that the respondents do not use mass media tools in receiving agricultural information as it should. This low use of mass media in receiving agricultural information could result to low standard of living and poor rural life. This assertion can be made from the findings of Nazari et al (2012) that mass media offer effective channel for communicating agricultural messages, which can increase knowledge and influence behaviour of audience members. When knowledge increases, the adoption rate will increase and this will result to increase in production as well as the standard of living and welfare of the rural populace.

\section{Perceived effectiveness of ADP's use of mass media in agricultural information dissemination}

Table 3 shows the perceived level of effectiveness of ADP's use of mass media in agricultural information dissemination. The result showed that the majority (59.2\%) indicated mass media as a means of agricultural information dissemination as ineffective. It can therefore be said that the use of mass media in agricultural information dissemination has not produced the expected result. This assertion is made from the definition of effectiveness by Khan, Rahman and Uddin (2017) as the influence or capacity or validity of something to produce expected result.

\section{Relationship between the perceived level of use of mass media in receiving agricultural information and perceived effectiveness of ADP's use of mass media in agricultural information dissemination}

The result on Table 4 shows that there was a significant relationship between the level of use of mass media in receiving agricultural information $(\mathrm{r}=0.649, \mathrm{p} \leq 0.05)$ and the perceived effectiveness of ADP's use of mass media in agricultural information dissemination. This means that there is a correlation between the two. This also means that for mass media to be effective in agricultural information dissemination there has to be a high level of use of it in receiving agricultural information.

This implies that level of use of mass media in receiving agricultural information affects its effectiveness in agricultural information dissemination. This is in line with the findings of Memon et al (2014) that the farmers who used mass media tools in receiving agricultural information reported that there was infrastructural development due to the agricultural information received through mass media. They also reported the relevance of the information received in solving agricultural problems and capacity building. Some of these are measure of effectiveness. 


\section{CONCLUSION AND RECOMMENDATION}

Evident from the study is that the perceived level of use of mass media in receiving agricultural information was low. Likewise, the use of mass media in receiving agricultural information was ineffective. Therefore, for now, mass media has not made a notable impact in agriculture in the study area. This work therefore recommends the establishment of an indigenous mass media outfit by ADP to ensure effective use of mass media for agricultural information dissemination. 


\section{REFERENCES}

Adikari, P. (2014). Usage of mass Media by famers in Sri Lanka; Developing Country Studies. Vol. 4(4), Pp. 1-4.

Ani, A. O. and Baba, S. A.(2009). Utilization of Selected Electronic Mass Media as Sources of Agricultural, Information by Farmers in Northern Taraba State, Nigeria. Tropical Agricultural Research and Extension I2(1): 17-22.

Ani, A. O. Undiandeye, U. C. and Anogie, D. A. (1997). The Role of Mass Media in Agricultural Information in Nigeria. Educational forum. Vol. 391, Pp. 80-85.

Bello, M. and Obinne, C.P.O (2012). Problems and prospects of agricultural information sources utilization by small scale farmers: A case from Nasarawa State, Nigeria: Journal of Communication, 3(2), 91-98

Cambridge University Press. (2009). Cambridge advanced learner's dictionary. Retrieved November $\quad 9,2009 \quad$ from $\quad 2$ http://dictionary. cambridge.org/define.asp/key=22599\&amp:did=CALD

Chikaire, J.U; Nwakwasi, R.N and Godson-Ibeji, C.C (2016). An Analysis of the Perceived Effects of Climate Change on the Health of Rural Farmers in Okigwe Agricultural Zone of Imo State, Nigeria. Mayfair Journal of Agricultural Development in Emerging Economics (MJADEE).

Iniovorua, E., Nwaiwu, I.U.O and Ogbonna, S. (2016). Determinants of credit accessibility by farmers in Owerri Agricultural Zone, Imo State, Nigeria. Asian Journal of Agricultural Extension, Economics and Sociology vol.12(1); Pp. 1-7.

Khan, Rahman and Uddin (2017) Effectiveness of Selected Mass Media in Agricultural Technology Transfer to the Farmer of Bangladesh. An open Access Peer Reviewed Journal Vol.4(1). Pp. 7-13.

Memon, I., Panhwar, K. N., Chandio, R. A., Bhutto, A. L., and Khooharo, A. A. (2014). Role of Mass Media in Dissemination of Agricultural Technology among the Farmers of Jaffarabad District of Balochislan: Journal of Basic and Applied Sciences, Vol. 10, Pp. $525-531$.

Merriam Webster Dictionary (2017) Information/ Definition of Information by MerriamWebster. Retrieval on $5^{\text {th }}$ November 2017 from https:www.merriam-webster.com>info retrieved.

Nazari, M. R., Hassan S.B, Parhizkar S., Hassanpour, B., and Yasin, M. A. B. (2012). Role of Broadcast Media in the Dissemination of Agricultural Knowledge. Archives Des Sciences, Vol. 65(3), Pp. 45-55. 
Njoku, J. I. K. (2016). Effectiveness of Radio-Agricultural Farmer Programme in Technology Transfer among Rural Farmers in Imo State, Nigeria. Net, J. Agric. Sci., Vol. 4(2), Pp. $22-28$.

Nwankwo, O. O. and Orji, O. (2013). Assessment of Mass Media Contributions to Agricultural Technology Adoption in Owerri Agricultural zone of Imo State, Nigeria. Global Advanced Research Journal of Management and Business Studies, Vol. 2(7) Pp. 389-394.

Omonijo, D.O., Toluwase S.O., Oludayo W.O., and Uche O.O (2014). Impact of Agricultural Development Programme (ADP) on rural dwellers in Nigeria: A case study of Isan-Ekiti. International Research Journal of Finance and Economics 128:41-55.

Sharma, D. (2012). Mass media utilization pattern of farm women. International Journal of Scientific and Research Publications Vol (2). Pp1-3

Umerah, M.I (2012) Comparative Assessment of Mass Media Usage by Poultry Farmers in Anambra and Enugu States of Nigeria. M.Sc Thesis Presented to the Department of Agricultural Extension, University of Nigeria, Nsukka. Pp. 25-26. 


\section{APPENDIXES}

Table 1: Farmer's accessibility to agricultural information through mass media

\begin{tabular}{ll}
\hline Mass media tools & Percentage \\
\hline Radio & 88.3 \\
Television & 44.2 \\
Telephone & 2.5 \\
Internet & 12.5 \\
\hline
\end{tabular}

Table 2: Perceived level of use of mass media in receiving agricultural information

\begin{tabular}{ll}
\hline Categorization & Percentage \\
\hline Low $(37-47)$ & 58.3 \\
High (48-66) & 41.7 \\
Total & 100 \\
\hline
\end{tabular}

Table 3: Perceived effectiveness of ADP's use of mass media in agricultural information dissemination

\begin{tabular}{ll}
\hline Categorization & Percentage \\
\hline Low (40-54) & 59.2 \\
High (54-85) & 40.8 \\
Total & 100 \\
\hline
\end{tabular}

Journal of the Faculty of Agriculture and Veterinary Medicine, Imo State University Owerri website: www ajol.info 
Akwiwu, Uzoamaka N. and Patrick, Ruby E. ${ }^{44}$ Volume 17 Number 2, October 2019 pp 34 - 44.

Table 4. Relationship between perceived level of use of mass media in receiving agricultural information and perceived effectiveness of ADP's use of mass media in agricultural information dissemination

\begin{tabular}{ll} 
Variables r-value \\
\hline
\end{tabular}

Level of use of mass media in receiving 0.649

agricultural information

Significant @ $\mathbf{p} \leq \mathbf{0 . 0 5}$

Journal of the Faculty of Agriculture and Veterinary Medicine, Imo State University Owerri website: www ajol.info 